\title{
Teaching NeuroImages: Medically intractable epilepsy and ictal asystole treated with cardiac pacing
}

Nicholas M. Gregg, MD, Kate W. Hocquard, MD, David B. Burkholder, MD, and Terrence D. Lagerlund, MD, PhD

Neurology ${ }^{\circledR}$ 2019;92:e2510-e2511. doi:10.1212/WNL.0000000000007546

Correspondence

Dr. Gregg

Gregg.nicholas@mayo.edu

Figure 1 Right temporal onset seizure and ictal asystole

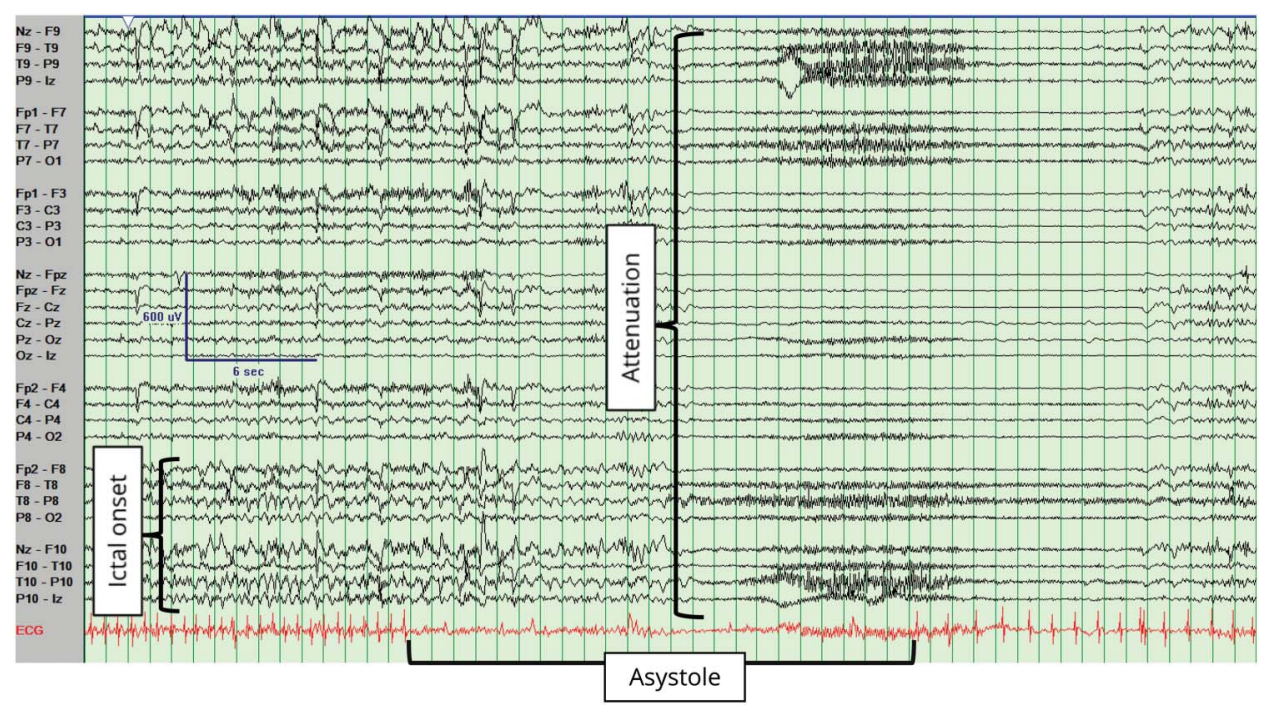

Right posterior temporal onset seizure with 24-second ictal asystole and associated generalized EEG attenuation with superimposed myogenic artifact. Longitudinal anatomic bipolar montage with subtemporal coverage.
A 43-year-old man with bihemispheric periventricular nodular heterotopia had medically intractable multifocal epilepsy and seizure-related falls. Video-EEG recorded a seizure with ictal asystole, EEG attenuation, and loss of postural tone, reflective of cerebral hypoperfusion (figure 1). After pacemaker implantation, EEG recorded a seizure with ictal cardiac pacing, without EEG attenuation (figure 2). His falls resolved. Antiseizure medications and epilepsy surgery can control seizures and ictal asystole. ${ }^{1}$ For individuals with intractable epilepsy and ictal asystole who are poor surgical candidates, pacemaker implantation is indicated to prevent injury and any potential contribution of ictal asystole in sudden unexpected death in epilepsy. ${ }^{1,2}$

\section{Disclosure}

The authors report no disclosures relevant to the manuscript. Go to Neurology.org/N for full disclosures.

\section{Study funding}

No targeted funding reported.

\section{MORE ONLINE}

$\rightarrow$ Teaching slides

links.lww.com/WNL/

A890 
Figure 2 Left temporal onset seizure and ictal cardiac pacing

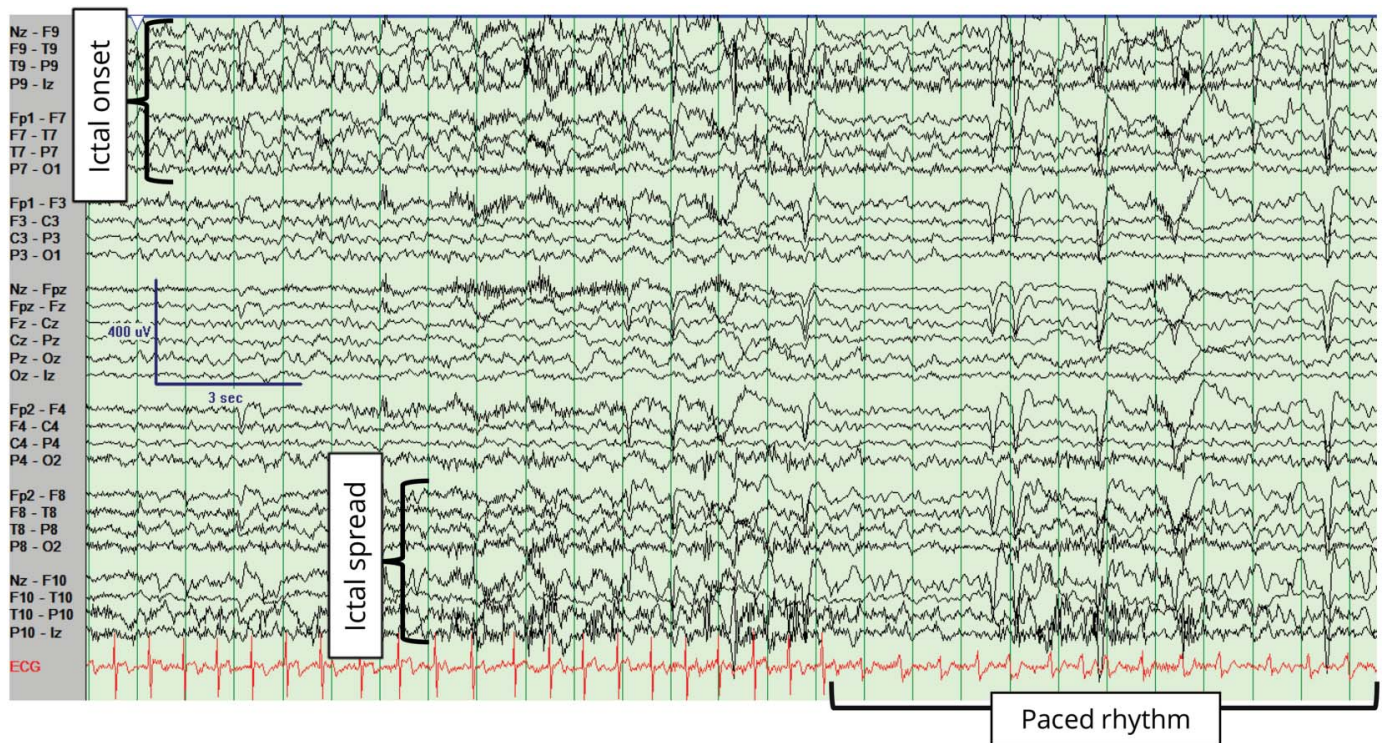

Left posterior temporal onset seizure, with right temporal spread, loss of normal cardiac rhythm, and onset of paced cardiac rhythm lasting 17 seconds.

Appendix Authors

\begin{tabular}{llll}
\hline Name & Location & Role & Contribution \\
\hline $\begin{array}{l}\text { Nicholas } \\
\text { Gregg, MD }\end{array}$ & $\begin{array}{l}\text { Mayo Clinic, } \\
\text { Rochester, MN }\end{array}$ & Author & $\begin{array}{l}\text { Conceptualized the article, } \\
\text { analyzed the data, drafted } \\
\text { the manuscript for } \\
\text { intellectual content }\end{array}$ \\
\hline $\begin{array}{l}\text { Kate } \\
\text { Hocquard, } \\
\text { MD }\end{array}$ & $\begin{array}{l}\text { Mayo Clinic, } \\
\text { Rochester, MN }\end{array}$ & Author & $\begin{array}{l}\text { Data collection, drafting and } \\
\text { revision of manuscript }\end{array}$ \\
\hline $\begin{array}{l}\text { David } \\
\text { Burkholder, } \\
\text { MD }\end{array}$ & $\begin{array}{l}\text { Mayo Clinic, } \\
\text { Rochester, MN }\end{array}$ & Author & $\begin{array}{l}\text { Data collection, drafting and } \\
\text { revision of manuscript }\end{array}$ \\
\hline $\begin{array}{l}\text { Terrence } \\
\text { Lagerlund, } \\
\text { MD }\end{array}$ & $\begin{array}{l}\text { Mayo Clinic, } \\
\text { Rochester, MN }\end{array}$ & Author & $\begin{array}{l}\text { Data collection, drafting and } \\
\text { revision of manuscript }\end{array}$ \\
\hline & & & \\
\hline
\end{tabular}

\section{References}

1. Strzelczyk A, Cenusa M, Bauer S, et al. Management and long-term outcome in patients presenting with ictal asystole or bradycardia. Epilepsia 2011;52:1160-1167. 2. Hampel KG, Thijs RD, Elger CE, Surges R. Recurrence risk of ictal asystole in epilepsy. Neurology 2017;89:785-791. 


\section{Neurology}

\section{Teaching NeuroImages: Medically intractable epilepsy and ictal asystole treated with cardiac pacing}

Nicholas M. Gregg, Kate W. Hocquard, David B. Burkholder, et al.

Neurology 2019;92; $2510-\mathrm{e} 2511$

DOI 10.1212/WNL.0000000000007546

This information is current as of May 20, 2019

\section{Updated Information \& Services}

References

Citations

Subspecialty Collections

Permissions \& Licensing

Reprints including high resolution figures, can be found at: http://n.neurology.org/content/92/21/e2510.full

This article cites 2 articles, 1 of which you can access for free at: http://n.neurology.org/content/92/21/e2510.full\#ref-list-1

This article has been cited by 1 HighWire-hosted articles: http://n.neurology.org/content/92/21/e2510.full\#\#otherarticles

This article, along with others on similar topics, appears in the following collection(s):

All Clinical Neurology

http://n.neurology.org/cgi/collection/all_clinical_neurology

All Epilepsy/Seizures

http://n.neurology.org/cgi/collection/all_epilepsy_seizures

EEG

http://n.neurology.org/cgi/collection/eeg_

Epilepsy monitoring

http://n.neurology.org/cgi/collection/epilepsy_monitoring_

Information about reproducing this article in parts (figures,tables) or in its entirety can be found online at:

http://www.neurology.org/about/about_the_journal\#permissions

Information about ordering reprints can be found online:

http://n.neurology.org/subscribers/advertise

Neurology ${ }^{\circledR}$ is the official journal of the American Academy of Neurology. Published continuously since 1951, it is now a weekly with 48 issues per year. Copyright () 2019 American Academy of Neurology. All rights reserved. Print ISSN: 0028-3878. Online ISSN: 1526-632X.

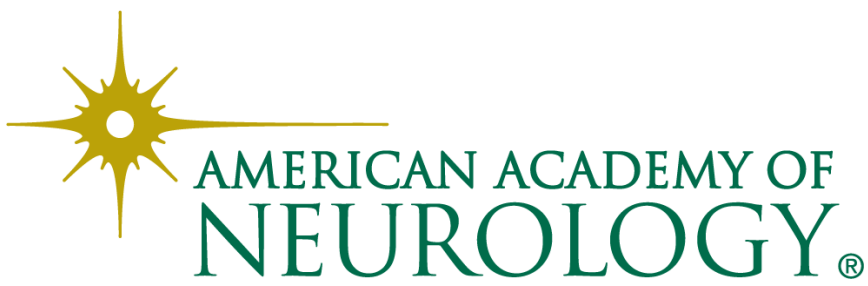

